\title{
Recurrent constructional pattern of the crustacean burrow Sinusichnus sinuosus from the Paleogene and Neogene of Spain
}

Zain Belaústegui, Jordi M. De Gibert, Miguel López-Blanco, and Ildefonso Bajo

Acta Palaeontologica Polonica 59 (2), 2014: 461-474 doi: http://dx.doi.org/10.4202/app.2012.0092

New occurrences of Sinusichnus sinuosus described in the Cenozoic of Spain evidence the almost continuous fossil record of this ichnospecies from the Upper Cretaceous to the Lower Pliocene. Morphological and size features of these highly regular sinusoidal burrows have been analyzed, showing a very recurrent constructional pattern through time. Such features are also constant along the ontogeny of the producer. The large number of similarities that this ichnogenus shares with fodinichnial burrow systems, such as Thalassinoides, Ophiomorpha, or Spongeliomorpha, point to a crustacean authorship. Since this sinusoidal architecture is also common among some graphoglyptids, other behavioral strategies are discussed. The ichnogenus Sinusichnus occurs commonly in shallow marine environments, in particular to deltaic depositional settings.

Key words: Decapoda, Sinusichnus sinuosus, Bioturbation, Eocene, Miocene, Pliocene.

Zain Belaústegui [zbelaustegui@ub.edu] and Miguel López-Blanco [m.lopezblanco@ub.edu ], Departament d'Estratigrafía, Paleontologia i Geociències Marines, Universitat de Barcelona, Martí i Franquès s/n, 08028 Barcelona, Spain; Ildefonso Bajo [ildebajo@gmail.com], Sección de Paleontología, Museo de la Ciudad, Juez Pérez Díaz, s/n, 41500 Alcalá de Guadaíra, Spain. Jordi M. de Gibert passed away on September 23th, 2012.

This is an open-access article distributed under the terms of the Creative Commons Attribution License (for details please see creativecommons.org), which permits unrestricted use, distribution, and reproduction in any medium, provided the original author and source are credited. 
Farif Full text $(1,358.4 \mathrm{kB})$ 